\title{
The importance of the multiplex ligation-dependent probe amplification in the identification of a novel two-exon deletion of the NR5A1 gene in a patient with $46, \mathrm{XY}$ differences of sex development
}

\author{
Orsolya Nagy' ${ }^{1}$ Judit Kárteszi ${ }^{2} \cdot$ Marianna Hartwig $^{2} \cdot$ Rita Bertalan $^{3} \cdot$ Eszter Jávorszky $^{3,4} \cdot$ Éva Erhardt $^{5}$. \\ Attila Patócs ${ }^{6} \cdot$ Tamás Tornóczky $^{7} \cdot$ István Balogh $^{1} \cdot$ Anikó Ujfalusi $^{1}$
}

Received: 14 March 2019 / Accepted: 11 July 2019 / Published online: 23 July 2019

(c) The Author(s) 2019

\begin{abstract}
Gonadal dysgenesis (GD) is a rare cause of differences of sex development (DSD) with highly variable clinical and genetic conditions. Although identification of the causative genetic alterations can offer a clearer prognosis and personalized management to patients, more than $50 \%$ of the DSD cases still do not have an accurate genetic diagnosis. NR5Al (previously known as $S F-1$ ), is a transcriptional regulator of genes required for normal development and functional maintenance of the gonads and the adrenal glands. Nucleotide sequence variants of the NR5Al gene have been reported in numerous patients with GD with or without adrenal failure, however, microdeletion or partial deletion in the NR5Al gene have been described only in a few GD cases. In this case study, we present a subject with female phenotype, mild clitoromegaly, partial GD and normal adrenal function. Cytogenetic analysis revealed a 46,XY SRY+ karyotype. Microarray analysis did not identify pathogenic copy number variations, nor did panel sequencing of the most common DSD genes. Subsequently, multiplex ligationdependent probe amplification (MLPA) was performed to test for small deletion/duplication of the most frequently affected genes associated with GD. Using this method, we have identified a novel heterozygous deletion involving exons 5 and 6 of the NR5Al gene as the cause of abnormal sexual development of the patient. This report expands our knowledge about the range and pathogenetic role of NR5A1 mutations associated with partial gonadal dysgenesis in 46,XY DSD. Furthermore, our data emphasises the indispensable role of MLPA in the diagnosis of DSD with unclear etiology.
\end{abstract}

Keywords Gonadal dysgenesis $\cdot$ NR5AI $\cdot$ MLPA $\cdot$ Novel partial deletion $\cdot$ 46,XY DSD

\section{Introduction}

Differences of sex development (DSD) are congenital conditions in which the development of chromosomal, gonadal and anatomical sex is atypical. The frequency of

Electronic supplementary material The online version of this article (https://doi.org/10.1007/s11033-019-04980-8) contains supplementary material, which is available to authorized users.

Anikó Ujfalusi

ujfalusi.aniko@med.unideb.hu

1 Division of Clinical Genetics, Department of Laboratory Medicine, Faculty of Medicine, University of Debrecen, Debrecen, Hungary

2 Hospital of Zala County, Zalaegerszeg, Hungary

3 1st Department of Pediatrics, Semmelweis University, Budapest, Hungary DSD is about 1 in 4500 live births [1]. The etiological background of DSD is extremely heterogeneous as it can

4 MTA-SE Lendulet Nephrogenetic Laboratory, Budapest, Hungary

5 Department of Pediatrics, University of Pécs, Pécs, Hungary

6 Endocrin Genetics Laboratory, Department of Laboratory Medicine, Semmelweis University, Budapest, Hungary

7 Department of Pathology, University of Pécs, Medical School, Pécs, Hungary 
be induced by numerical or structural sex chromosome aberrations, variations of genes involved in the gonadal and/or genitalal development or steroidogenesis, maternal factors, hormonal disturbances and epigenetic modifications [2-4].

Based on sex chromosomal content DSD are classified into three groups: sex chromosome DSD, 46,XX DSD and $46, X Y$ DSD [5]. In clinical practice, less than $50 \%$ of the DSDs with gonadal dysgenesis (GD) have specific molecular genetic diagnosis resulting from highly variable phenotype, heterogeneous genetic background and low genotype-phenotype correlation. Due to the high proportion of DSD cases with unknown genetic background, this field is still under intensive research. Heterozygous mutations of NR5Al is the most prevalent genetic cause in 46,XY DSD individuals, with a frequency of about 15-20\% [6]. NR5A1 (previously known as steroidogenic factor- $1, S F-1$ ) is a transcription factor that belongs to the nuclear receptor superfamily and regulates a number of genes involved in early development of bipotential gonads, in subsequent differentiation of the testes, and in steroidogenesis. Human NR5Al mutations were first reported in association with 46,XY DSD and adrenal insufficiency [7], but later studies revealed that mutations are more frequent in 46,XY DSD patients without adrenal failure $[8,9]$. Most commonly DSD is associated with ambiguous external genitalia, with or without Mullerian structures, due to variable degrees of testicular dysgenesis with compromised androgen and anti-Mullerian hormone (AMH) production [6]. The NR5Al gene, located on chromosome 9q33.3, is composed of 7 exons including the non-coding first exon [10]. To date, the identified variants are mainly missense, nonsense, splicing mutations, small deletions and insertions [11-13]. Large scale mutations, such as microdeletion of $9 \mathrm{q} 33$ chromosomal region or partial gene deletions involving NR5Al have been reported in only 5 cases with 46,XY DSD (Table 1) [14-18].
In this study, we present a novel mutation of the NR5AI gene in a female patient with 46,XY karyotype and GD. The genetic alteration, a small partial deletion including exon 5 and 6 , was identified by multiplex ligation-dependent probe amplification (MLPA). This case is the first report of a de novo exon 5 and 6 deletion of the NR5Al gene identified in 46,XY DSD. Our finding shows that although intragenic copy number alterations are a rare cause of GD, testing for these genetic variations should be considered in DSD patients with unknown etiology.

\section{Materials}

The proband is the first child of non-consanguineous Caucasian healthy parents. Family history was negative for DSD, premature ovarian failure (POF), fertility problems or any genetic disease. The patient was born after an uneventful pregnancy at 36 weeks of gestation with a birth weight of $3200 \mathrm{~g}$. At birth clinodactyly of the 5th fingers and 2-3 toe cutaneous syndactyly were noticed on both sides. Both of these are common isolated malformations in the general population. External genitalia showed female appearance with slight clitoromegaly (Prader stage I). At 9 months of age, the child was admitted to a hospital because of abdominal pain and vomiting. Bilateral inguinal hernias were found with gonads, suspected testes, during transabdominal ultrasonography (US). Upon laparoscopy mixed internal genitalia with a very small uterus, fallopian tubes and epididymis were detected. Biopsy of the gonads identified testicular tissue with no spermatogonia and a small number of Leydig cells. The gonads were placed into the abdomen. At that time G-banded chromosome analysis was performed and a $S R Y$ positive 46,XY karyotype was revealed. Complete androgen insensitivity syndrome was excluded based on low testosterone level $(<0.15 \mathrm{nmol} / \mathrm{L})$.

Table $146, \mathrm{XY}$ DSD cases with deletions containing NR5A1 gene

\begin{tabular}{|c|c|c|c|c|c|}
\hline Size of deletion & Clinical and gonadal phenotype & Other symptoms & Genetic testing & Inheritance & References \\
\hline $3.07 \mathrm{Mb}$ & Clitoromegaly, ovotestis, absence of uterus & Genitopatellar syndrome & Array CGH & Not done & Schlaubitz et al. [17] \\
\hline $1.54 \mathrm{Mb}$ & Female external genitalia & $\begin{array}{l}\text { Mild mental retardation, } \\
\text { minor dysmorphism }\end{array}$ & Array CGH & De novo & Brandt et al. [15] \\
\hline $0.97 \mathrm{Mb}$ & $\begin{array}{l}\text { Clitoromegaly, absence of uterus or Muller- } \\
\text { ian structure, fusion of the labia majora, } \\
\text { shallow vaginal entrance, gonad in the left } \\
\text { labium }\end{array}$ & Left-sided ptosis & Array CGH & De novo & van Silfhout et al. [18] \\
\hline $0.24 \mathrm{Mb}$ & $\begin{array}{l}\text { Ambiguous genitalia with perineal hypo- } \\
\text { spadiasis, bilateral gonads palpable in the } \\
\text { labioscrotal folds }\end{array}$ & - & Array CGH & Maternal & Harrison et al. [16] \\
\hline $3.1-4.8 \mathrm{~kb}$ & $\begin{array}{l}\text { Leydig cell hyperplasia, scarce germ cells, } \\
\text { carcinoma in situ }\end{array}$ & - & Custom MLPA & Not done & Barbaro et al. [14] \\
\hline Max. $7.642 \mathrm{~kb}$ & $\begin{array}{l}\text { Clitoromegaly, absence of uterus, blind-end- } \\
\text { ing vagina, dysgenetic gonads }\end{array}$ & - & MLPA & De novo & This study \\
\hline
\end{tabular}


Gonadotropin hormone levels were the following: folliclestimulating hormone (FSH): $6.4 \mathrm{mIU} / \mathrm{L}$ (ref.: $0.1-6 \mathrm{mIU} / \mathrm{L}$ ), luteinizing hormone (LH): $1.5 \mathrm{mIU} / \mathrm{L}$ (ref.: $0.1-4 \mathrm{mIU} / \mathrm{L}$ ). The patient had normal serum cortisol and adrenocorticotropin hormone values and there was no evidence of adrenal insufficiency. The parents raised their baby as a female and the child was referred to an endocrinologist only at the age of 5 years when the transabdominal US examination failed to show Mullerian structures and magnetic resonance imaging (MRI) could not identify an uterus. At that time the AMH level was $87.3 \mathrm{pmol} / \mathrm{L}$, above the normal female (2-32 pmol/L) and below the normal male reference value (400-1300 pmol/L), this suggested clinical diagnosis of partial gonadal dysgenesis, a form of 46,XY DSD, consistent with the results of the earlier histology examination of the gonads. At 5.5 years of age, laparoscopy and a urethra-cystovaginoscopy was done and gonadectomy was performed to clarify the diagnosis and prevent tumorous transformation of the dysgenic testes. A blinded end vagina was identified, but uterus could not be found. Histological examination showed testicular parenchyma, epididymis and a small part of ductus deferens with a piece of tissue resembling the fallopian tube in the right side gonad $(10 \times 5 \times 7 \mathrm{~mm})$, while in the left side gonad $(16 \times 80 \times 70 \mathrm{~mm})$ testicular and epididymidis tissues were found. The seminiferous tubules showed only Sertoli cells without spermatogonia on both sides (Fig. 1). These examinations confirmed the diagnosis of $46, \mathrm{XY}$ with a highly suspected genetic background.

\section{Methods}

G-banded chromosome analysis was carried out on cultured lymphocytes using standard protocols. Fluorescence in situ hybridization (FISH) was performed according to the manufacturer's instructions using locus probe for $S R Y$ gene and the centromeric region of chromosome X (Cytocell, Rainbow Scientific Inc., Windsor, CT). Genomic DNA for molecular genetic studies was extracted from peripheral blood leukocytes using QIAamp DNA Blood Mini Kit (Qiagen, Hilden, Germany). Array comparative genomic hybridization (CGH) was performed using CytoScan $750 \mathrm{~K}$ Array as specified by the manufacturer with overall average prober spacing 4.125 bp per probe (Affymetrix, Thermo Fisher Scientific, Waltham, Massachusetts). Affymetrix Chromosome Analysis Suite (ChAS) Software was used for analysis. Exome sequencing was performed using Complete Genomics platform by the Beijing Genomics Institute. Targeted analysis of known genes involved in DSD was performed. MLPA was performed using SALSA MLPA P185-C2 Intersex probemix containing selected exons of the following genes: NROB1 (DAX1), CXorf21 (Xp21.2), SOX9 (17q24.3), $S R Y$ and ZFY (Yp11.3), WNT4 (1p36.12), NR5Al (9q33) (MRC-Holland, Amsterdam, The Netherlands). Amplified products were separated by size on ABI-3130 (Applied Biosystems, Foster City, CA) and data were analyzed by the Coffalyser.Net Software (MRC-Holland, Amsterdam,
Fig. 1 a Histology of the right gonad (Hematoxilin Eosin (HE) staining, $20 \times$ magnification); b Histology of the left gonad (HE staining, $20 \times$ magnification); c Seminiferous tubules with only Sertoli cells present (HE staining, approx. $400 \times$ magnification); d Seminiferous tubules with only Sertoli cells present (inhibin alpha immunohistochemistry, approx. $400 \times$ magnification)

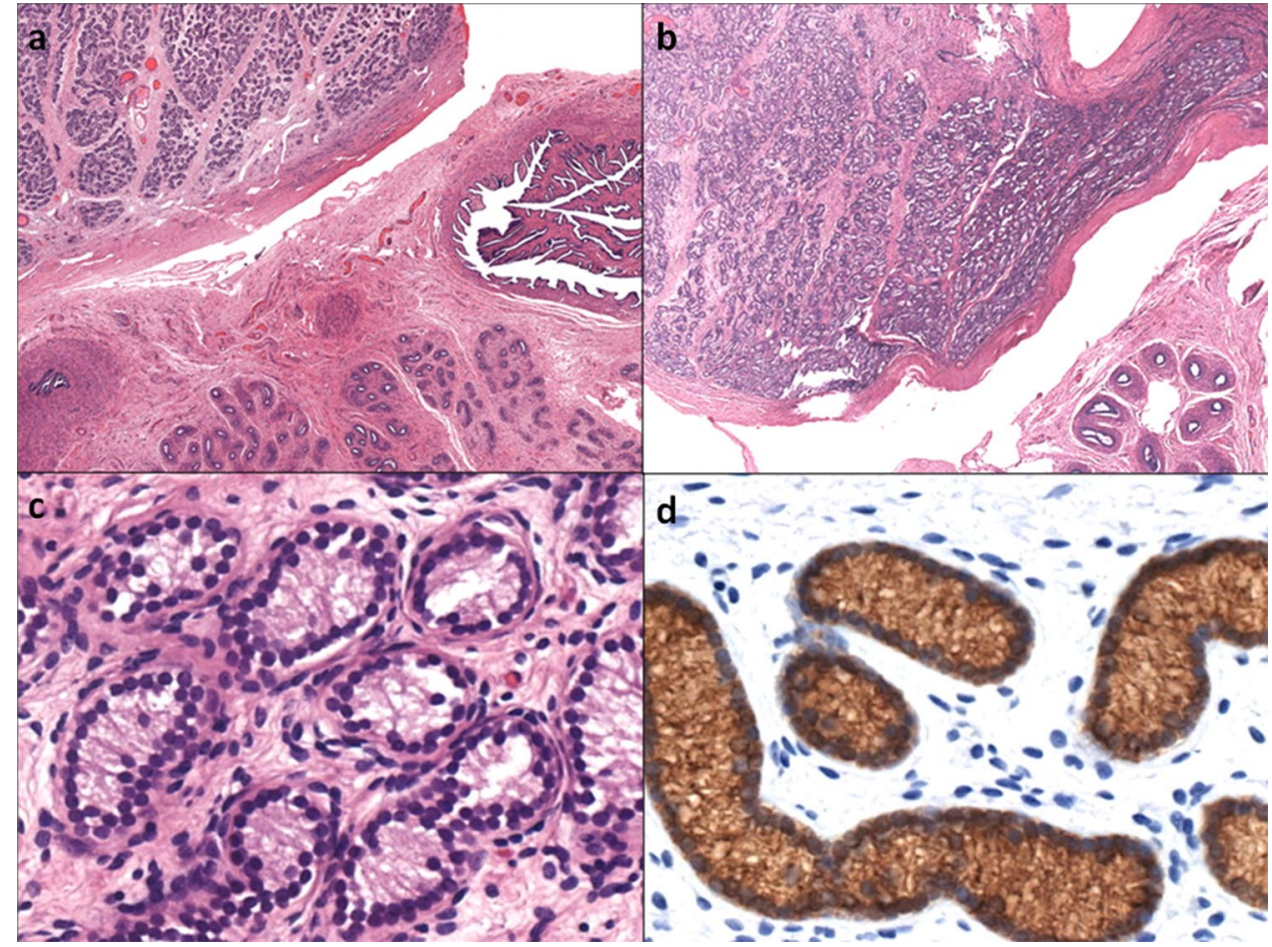



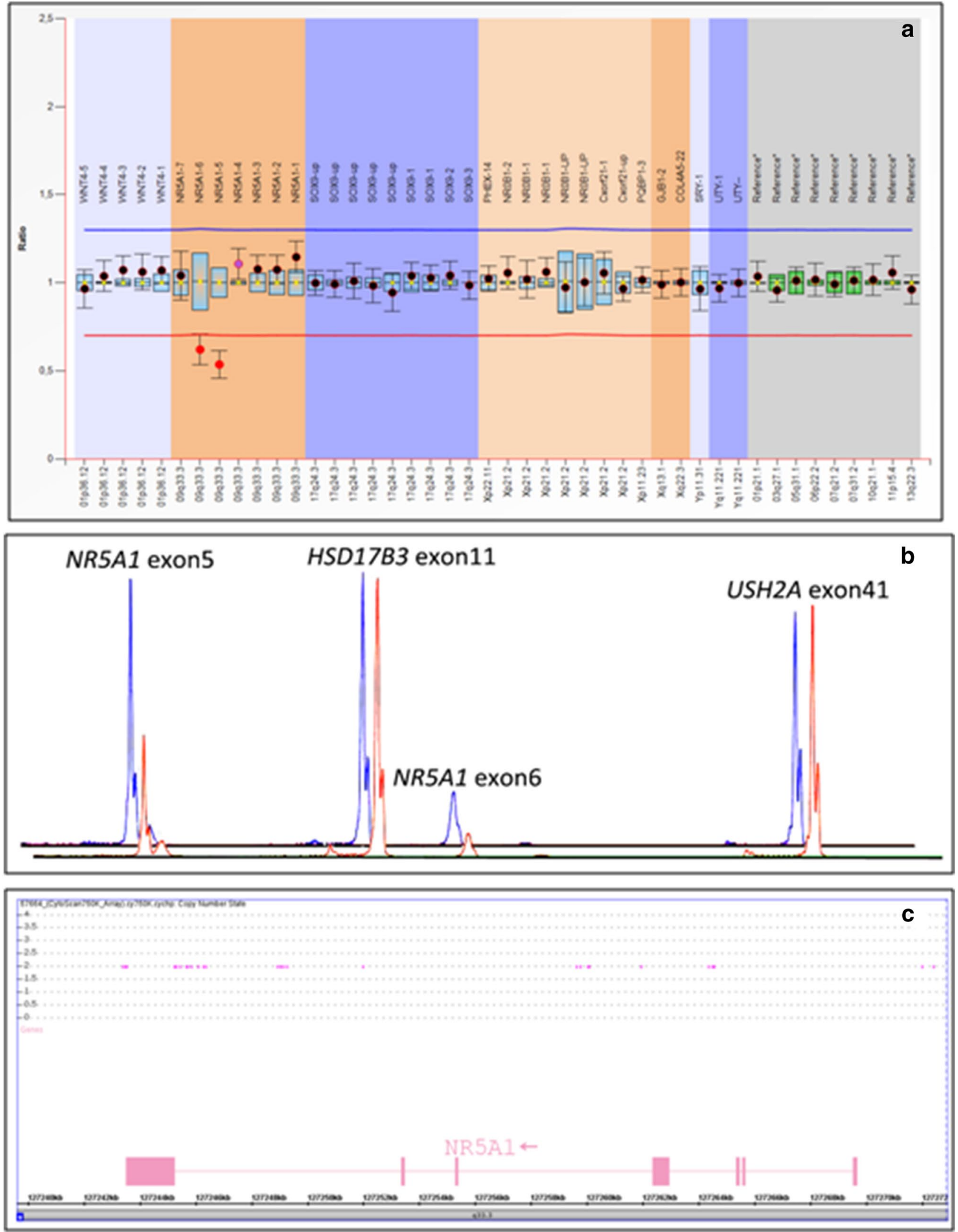
4 Fig. 2 a Result of MLPA analysis. Sample was normalized using the average of 2 normal controls. Red dots show a heterozygous deletion of exons 5 and 6 of the NR5A1 gene. Chromosomal locations are displayed on the $\mathrm{x}$-axis and the y-axis represents dosage quotient (Ratio). Normal copy number is between 0.65 to 1.30 . b Electropherograms of the patient with heterozygous deletion (in red), superimposed on the electropherograms of a control subject (in blue). Whereas control regions (HSD17B3 and USH2A) show a similar peak height in the patient and control, heterozygous deletion reduces the peak height (NR5A1 exon 5 and 6) by half. c Array CGH result of the patient shows that exons 5 and 6 of NR5Al gene is not covered by copy number probes (exon numeration from left to right, exon 1-7). The genomic position of presenting probes before exon 5 is $127,259,618$ within intron 4 and after exon 6 is 127,251,976 within intron 6 (GRCh37). (Color figure online)

The Netherlands). A peak was considered abnormal when the ratio was $<0.65$ (deletion) or $>1.30$ (duplication) compared to the peaks of the reference probes. QMPSF (Quantitative Multiplex PCR of Short Fluorescent Fragments) conditions and primer sequences are detailed in Supplementary Material.

Peripheral blood samples were collected from the proband after obtaining informed consent according to national regulations including permission of the parents for publication of the medical details. The MLPA study was approved by the Ethics Committee of the Ministry of Human Capacities (\# RITK-MULTI-001).

\section{Results}

Routine cytogenetic studies revealed $S R Y$ positive $46, \mathrm{XY}$ karyotype. Targeted gene panel analysis showed no pathogenic variants in DSD related genes. After excluding nucleotide sequence mutations, array $\mathrm{CGH}$ was performed to identify copy number alterations. Pathogenic copy number variation $(\mathrm{CNV})$ was not detected by the oligonucleotide array. Assuming that intragenic deletions/duplications may be responsible for GD, the most commonly affected DSD genes were screened by MLPA. A heterozygous partial deletion encompassing exons 5 and 6 of the NR5Al gene was identified (Fig. 2a). Probes targeting all other exons of the NR5A1 gene showed normal copy number. QMPSF assay confirmed the two-exon deletion (Fig. 2b). This small intragenic deletion could not be detected by the formerly used oligonucleotide array as exons 5 and 6 were not covered by the CNV probes. The two CNV probes that showed normal copy numbers proximal and distal to the deletion were located in introns 4 and 6 suggesting intronic breakpoints of the deletion (Fig. 2c). Family studies confirmed the de novo origin of the mutation that was undetectable in the genomic DNA of the parents. Diagnosis of $46, X Y$ DSD with partial gonad dysgenesis was indicated.

\section{Discussion}

We report a case study of a patient with female external genitalia, clitoromegaly, absent uterus, blind-ending vagina and dysgenetic gonads with mixed tissues consisting of testis, epididymis, ductus deferens and tuba uterina. The proband also manifested mild dysmorphic features. Chromosome analysis revealed $S R Y$ positive 46,XY DSD. Clarification of the genetic background started with targeted DSD gene panel analysis and whole genome array $\mathrm{CGH}$, both of these tests detected no pathogenic variants. MLPA analysis of DSD related genes identified a new partial heterozygous deletion within the NR5Al gene including exon 5 and 6 . The genetic alteration was confirmed by QMPSF method. To our knowledge, the patient is the first reported case carrying mutation affecting exons 5 and 6 of the NR5Al gene.

46,XY DSD may include complete or partial gonadal dysgenesis due to disturbances in testis differentiation or undervirilization/undermasculinization as a result of aberrant androgen synthesis or action. The most common gene mutations associated with 46,XY DSD include ARX, ATRX, CBX2, DAX1, DHH, DMRT1, EMX2, ESR2, FGFR2, GATA4, HHAT, MAP3K1, NR5A1, SOX8, SOX9, SRY, TSPYL1, WNT4, WT1, ZFPM2, and ZNRF3 [2, 19].

The NR5A1 protein is a transcription factor necessary for the expression of key genes involved in male sex differentiation (e.g. $S O X 9, S R Y)$ that along with the product of the WT1 gene, regulates expression of AMH by Sertoli cells leading to regression of the Mullerian structures. In testicular Leydig cells, it stimulates the expression of enzymes required for testosterone biosynthesis that are essential for Wolffian duct development and formation of external genitalia [12]. Targeted deletion of $\mathrm{Nr} 5 \mathrm{al}$ in $\mathrm{XY}$ mice cause adrenal and GD, sex reversal with female external genitalia and persistence of Mullerian structures [20].

In humans, loss of function mutations of the NR5Al gene are associated with higly variable clinical conditions including male factor infertility, hypospadias, undescended testes, bilateral anorchia, primary ovarian insufficiency (in 46,XX female), GD and in rare cases adrenal insufficiency. To date, more than 40 NR5Al heterozygous mutations have been described in 46,XY GD [12] with no clear genotype-phenotype relationships established. In contrast to nucleotide sequence mutations, CNVs are extremely rarely detected in 46,XY DSD individuals [21, 22]. Significant numbers of urogenital defects are associated with major congenital malformations or minor abnormalities, which is highly suggestive of chromosomal alterations as etiological factors [23]. While conventional karyotyping due to its limited resolution $(5-10 \mathrm{Mb})$ is not 
suitable to identify most of these aberrations, array $\mathrm{CGH}$ and MLPA have permitted the detection of submicroscopic $\mathrm{CNV}$ s throughout the genome and at gene level in DSD. A review by Kon and Fukami [24] in summarizing the results of 15 studies in which array CGH or MLPA were used to detect CNVs, emphasizes the significance of CNVs as one of the genetic causes of DSD. So far, all reported deletions or duplications were detected in heterozygous form leading to haploinsufficiency of the affected genes which may disturb sex developmental processes. The CNVs were mainly de novo and, in rare cases, POF has been described in carrier mothers. Only a few cases with CNVs involving the NR5Al gene have been published [14-18]. The reported CNVs are heterogeneous in regards to their sizes and clinical phenotypes. The clinical and genetic details of these cases and modes of inheritance are listed in Table 1.

The NR5A1 protein consists of a DNA-binding domain (DBD), two zinc finger domains, a hinge region, a ligandbinding domain (LBD) with 12-helix structure typical in nuclear receptors, and two activation function domains [25]. The LBD is composed of exon 4 (partial), exon 5, 6 and 7. In our case, the partial deletion affecting exons 5 and 6 results in a truncated $N R 5 A l$ gene. The mutation is out-of frame leading to a stop codon right after the coding part of exon 4, thus no functional NR5Al is synthesized from this allele. The other allele did not appear affected as exome sequencing did not reveal any sequence mutation in this allele. Based on these results haploinsufficiency of NR5Al can cause abnormal sexual development as observed in the proband.

In conclusion, a new partial deletion including exons 5 and 6 of the NR5Al gene was identified by MLPA in a female patient with 46,XY partial gonadal dysgenesis that represents a novel genetic cause of 46,XY DSD. Our results also emphasize the importance of MLPA suitable for the detection of small size CNV and intragenic deletions/duplications that can improve the diagnostic yield in routine practice. Molecular diagnosis is highly beneficial for DSD patients as it can help in the assessment of adrenal and gonadal functions, determining the risk of malignancy of the gonads, improving the accuracy of genetic counseling and developing personalized management. $\mathrm{CNV}$ s are extremely rarely detected in individuals with gonadal dysgenesis, investigation of these type of mutations is not part of the genetic diagnostic procedure. Based on our data targeted CNV analysis of DSD related genes including NR5Al by MLPA in routine genetic screening of patients with 46,XY DSD with unknown etiology should be considered.

Acknowledgements Open access funding provided by University of Debrecen (DE). This study was supported by the Ministry of National Economy, Hungary (GINOP-2.3.2-15-2016-00039).

\section{Compliance with ethical standards}

Conflict of interest The authors declare no conflict of interest.

Open Access This article is distributed under the terms of the Creative Commons Attribution 4.0 International License (http://creativeco mmons.org/licenses/by/4.0/), which permits unrestricted use, distribution, and reproduction in any medium, provided you give appropriate credit to the original author(s) and the source, provide a link to the Creative Commons license, and indicate if changes were made.

\section{References}

1. Hughes IA (2008) Disorders of sex development: a new definition and classification. Best Pract Res Clin Endocrinol Metab 22(1):119-134. https://doi.org/10.1016/j.beem.2007.11.001

2. Audi L, Ahmed SF, Krone N, Cools M, McElreavey K, Holterhus PM, Greenfield A, Bashamboo A, Hiort O, Wudy SA, McGowan R (2018) GENETICS IN ENDOCRINOLOGY: approaches to molecular genetic diagnosis in the management of differences/ disorders of sex development (DSD): position paper of EU COST Action BM 1303 'DSDnet'. Eur J Endocrinol 179(4):R197-R206. https://doi.org/10.1530/eje-18-0256

3. Piferrer F (2013) Epigenetics of sex determination and gonadogenesis. Dev Dyn 242(4):360-370. https://doi.org/10.1002/ dvdy.23924

4. Lee PA, Nordenstrom A, Houk CP, Ahmed SF, Auchus R, Baratz A, Baratz Dalke K, Liao LM, Lin-Su K, Looijenga LH III, Mazur T, Meyer-Bahlburg HF, Mouriquand P, Quigley CA, Sandberg DE, Vilain E, Witchel S (2016) Global disorders of sex development update since 2006: perceptions, approach and care. Horm Res Paediatr 85(3):158-180. https://doi.org/10.1159/000442975

5. Pasterski V, Prentice P, Hughes IA (2010) Impact of the consensus statement and the new DSD classification system. Best Pract Res Clin Endocrinol Metab 24(2):187-195. https://doi.org/10.1016/j. beem.2009.11.004

6. Domenice S, Machado AZ, Ferreira FM, Ferraz-de-Souza B, Lerario AM, Lin L, Nishi MY, Gomes NL, da Silva TE, Silva RB, Correa RV, Montenegro LR, Narciso A, Costa EM, Achermann JC, Mendonca BB (2016) Wide spectrum of NR5A1-related phenotypes in 46, XY and 46, XX individuals. Birth Defects Res Part C 108(4):309-320. https://doi.org/10.1002/bdrc.21145

7. Achermann JC, Ito M, Ito M, Hindmarsh PC, Jameson JL (1999) A mutation in the gene encoding steroidogenic factor-1 causes $\mathrm{XY}$ sex reversal and adrenal failure in humans. Nat Genet 22(2):125126. https://doi.org/10.1038/9629

8. Kohler B, Lin L, Mazen I, Cetindag C, Biebermann H, Akkurt I, Rossi R, Hiort O, Gruters A, Achermann JC (2009) The spectrum of phenotypes associated with mutations in steroidogenic factor 1 (SF-1, NR5A1, Ad4BP) includes severe penoscrotal hypospadias in 46, XY males without adrenal insufficiency. Eur J Endocrinol 161(2):237-242. https://doi.org/10.1530/eje-09-0067

9. Lin L, Philibert P, Ferraz-de-Souza B, Kelberman D, Homfray T, Albanese A, Molini V, Sebire NJ, Einaudi S, Conway GS, Hughes IA, Jameson JL, Sultan C, Dattani MT, Achermann JC (2007) Heterozygous missense mutations in steroidogenic factor 1 (SF1/Ad4BP, NR5A1) are associated with 46, XY disorders of sex development with normal adrenal function. J Clin Endocrinol Metab 92(3):991-999. https://doi.org/10.1210/jc.2006-1672

10. Oba K, Yanase T, Nomura M, Morohashi K, Takayanagi R, Nawata H (1996) Structural characterization of human Ad4 bp (SF-1) gene. Biochem Biophys Res Commun 226(1):261-267 
11. Eggers S, Sadedin S, van den Bergen JA, Robevska G, Ohnesorg T, Hewitt J, Lambeth L, Bouty A, Knarston IM, Tan TY, Cameron F, Werther G, Hutson J, O'Connell M, Grover SR, Heloury Y, Zacharin M, Bergman P, Kimber C, Brown J, Webb N, Hunter MF, Srinivasan S, Titmuss A, Verge CF, Mowat D, Smith G, Smith J, Ewans L, Shalhoub C, Crock P, Cowell C, Leong GM, Ono M, Lafferty AR, Huynh T, Visser U, Choong CS, McKenzie F, Pachter N, Thompson EM, Couper J, Baxendale A, Gecz J, Wheeler BJ, Jefferies C, MacKenzie K, Hofman P, Carter P, King RI, Krausz C, van Ravenswaaij-Arts CM, Looijenga L, Drop S, Riedl S, Cools M, Dawson A, Juniarto AZ, Khadilkar V, Khadilkar A, Bhatia V, Dung VC, Atta I, Raza J, Thi Diem Chi N, Hao TK, Harley V, Koopman P, Warne G, Faradz S, Oshlack A, Ayers KL, Sinclair AH (2016) Disorders of sex development: insights from targeted gene sequencing of a large international patient cohort. Genome Biol 17(1):243. https://doi.org/10.1186/s1305 9-016-1105-y

12. Suntharalingham JP, Buonocore F, Duncan AJ, Achermann JC (2015) DAX-1 (NR0B1) and steroidogenic factor-1 (SF-1, NR5A1) in human disease. Best Pract Res Clin Endocrinol Metab 29(4):607-619. https://doi.org/10.1016/j.beem.2015.07.004

13. Werner R, Monig I, August J, Freiberg C, Lunstedt R, Reiz B, Wunsch L, Holterhus PM, Kulle A, Dohnert U, Wudy SA, Richter-Unruh A, Thorns C, Hiort O (2015) Novel insights into 46, XY disorders of sex development due to NR5A1 gene mutation. Sex Dev 9(5):260-268. https://doi.org/10.1159/000442309

14. Barbaro M, Cools M, Looijenga LH, Drop SL, Wedell A (2011) Partial deletion of the NR5A1 (SF1) gene detected by synthetic probe MLPA in a patient with XY gonadal disorder of sex development. Sex Dev 5(4):181-187. https://doi.org/10.1159/00032 8821

15. Brandt T, Blanchard L, Desai K, Nimkarn S, Cohen N, Edelmann L, Mehta L (2013) 46, XY disorder of sex development and developmental delay associated with a novel 9q33.3 microdeletion encompassing NR5A1. Eur J Med Genet 56(11):619-623. https:// doi.org/10.1016/j.ejmg.2013.09.006

16. Harrison SM, Granberg CF, Keays M, Hill M, Grimsby GM, Baker LA (2014) DNA copy number variations in patients with 46, XY disorders of sex development. J Urol 192(6):1801-1806. https://doi.org/10.1016/j.juro.2014.06.040

17. Schlaubitz S, Yatsenko SA, Smith LD, Keller KL, Vissers LE, Scott DA, Cai WW, Reardon W, Abdul-Rahman OA, Lammer EJ, Lifchez CA, Magenis E, Veltman JA, Stankiewicz P, Zabel BU, Lee B (2007) Ovotestes and XY sex reversal in a female with an interstitial 9q33.3-q34.1 deletion encompassing NR5A1 and LMX1B causing features of Genitopatellar syndrome. Am J Med Genet Part A 143a(10):1071-1081. https://doi.org/10.1002/ ajmg.a.31685
18. van Silfhout A, Boot AM, Dijkhuizen T, Hoek A, Nijman R, Sikkema-Raddatz B, van Ravenswaaij-Arts CM (2009) A unique $970 \mathrm{~kb}$ microdeletion in 9q33.3, including the NR5A1 gene in a 46,XY female. Eur J Med Genet 52(2-3):157-160. https://doi. org/10.1016/j.ejmg.2009.02.009

19. Portnoi MF, Dumargne MC, Rojo S, Witchel SF, Duncan AJ, Eozenou C, Bignon-Topalovic J, Yatsenko SA, Rajkovic A, ReyesMugica M, Almstrup K, Fusee L, Srivastava Y, Chantot-Bastaraud S, Hyon C, Louis-Sylvestre C, Validire P, de Malleray Pichard C, Ravel C, Christin-Maitre S, Brauner R, Rossetti R, Persani L, Charreau EH, Dain L, Chiauzzi VA, Mazen I, Rouba H, SchluthBolard C, MacGowan S, McLean WHI, Patin E, Rajpert-De Meyts E, Jauch R, Achermann JC, Siffroi JP, McElreavey K, Bashamboo A (2018) Mutations involving the SRY-related gene SOX8 are associated with a spectrum of human reproductive anomalies. Hum Mol Genet 27(7):1228-1240. https://doi.org/10.1093/hmg/ ddy037

20. Luo X, Ikeda Y, Parker KL (1994) A cell-specific nuclear receptor is essential for adrenal and gonadal development and sexual differentiation. Cell 77(4):481-490

21. White S, Ohnesorg T, Notini A, Roeszler K, Hewitt J, Daggag H, Smith C, Turbitt E, Gustin S, van den Bergen J, Miles D, Western P, Arboleda V, Schumacher V, Gordon L, Bell K, Bengtsson H, Speed T, Hutson J, Warne G, Harley V, Koopman P, Vilain E, Sinclair A (2011) Copy number variation in patients with disorders of sex development due to $46, \mathrm{XY}$ gonadal dysgenesis. PLoS ONE 6(3):e17793. https://doi.org/10.1371/journal.pone.0017793

22. Croft B, Ohnesorg T, Sinclair AH (2018) The role of copy number variants in disorders of sex development. Sex Dev 12(1-3):19-29. https://doi.org/10.1159/000481896

23. Tannour-Louet M, Han S, Corbett ST, Louet JF, Yatsenko S, Meyers L, Shaw CA, Kang SH, Cheung SW, Lamb DJ (2010) Identification of de novo copy number variants associated with human disorders of sexual development. PLoS ONE 5(10):e15392. https ://doi.org/10.1371/journal.pone.0015392

24. Kon M, Fukami M (2015) Submicroscopic copy-number variations associated with 46, XY disorders of sex development. Mol Cell Pediatr 2(1):7. https://doi.org/10.1186/s40348-015-0018-2

25. Lin L, Achermann JC (2008) Steroidogenic factor-1 (SF-1, Ad4BP, NR5A1) and disorders of testis development. Sex Dev 2(4-5):200-209. https://doi.org/10.1159/000152036

Publisher's Note Springer Nature remains neutral with regard to jurisdictional claims in published maps and institutional affiliations. 